\title{
Characteristics of Trust among Successful Entrepreneurs in the Catering Services Industry in Malaysia
}

\author{
Suhaila Nadzri \\ Siti Syuhada Abd Rahman \\ Faculty of Management and Muamalah \\ Selangor International Islamic University College (KUIS), Bangi, MALAYSIA, \\ Islamic Hadhari Institute, Universiti Kebangsaan Malaysia, Bangi, MALAYSIA \\ Nuradli Ridzwan Shah Mohd Dali \\ Faculty of Economics And Muamalat, Universiti Sains Islam Malaysia \\ Mohamad Sabri Haron \\ University Citra Centre, Universiti Kebangsaan Malaysia \\ Islamic Hadhari Institute, Universiti Kebangsaan Malaysia, Bangi, MALAYSIA \\ Salmy Edawati Yaacob \\ Faculty of Islamic Studies, Universiti Kebangsaan Malaysia, Islamic Hadhari Institute \\ Universiti Kebangsaan Malaysia, Bangi, MALAYSIA
}

\begin{abstract}
In the current scenario, the catering services industry in Malaysia is growing rapidly and is dominated by Muslim entrepreneurs. However, there are many ethical issues related to dishonesty such as cases of fraud, dishonesty, breach of promises and treachery associated with catering services reported in electronic and print media. Therefore, this study was conducted to explore the practice of trust among successful entrepreneurs in the catering services industry in the state of Selangor. This study is qualitative in nature through a semi-structured interview with eight successful entrepreneurs in the food and catering industry in the state of Selangor who have been in business for at least 10 years. Transcribed interview data were analysed using Atlas-ti-8 software to extract the required themes and categories. The study found that successful catering entrepreneurs emphasize the three elements of trust, namely responsibility, keeping promises, and being fair. These findings are in line with the Prophetic Leadership Management Wisdom (PROLM) model presented by Syafii Antonio (2013). However, there are four new elements of trust, namely avoiding usury or corruption, integrity, always remembering Allah, and avoiding the treachery that is also practiced by these successful entrepreneurs. It is hoped that this study can be used as a guide by Muslim entrepreneurs, especially in Malaysia to always practice trust that can help them be more successful and competitive in business.
\end{abstract}

Key words: Trust, Entrepreneur, Success, Catering, Food

\section{Introduction}

Catering services industry in Malaysia has grown rapidly in the last ten years. Catering services, as one of the branches in the hospitality industry, is divided into several types such as restaurant services, contract catering, booking catering, transportation catering, and mobile catering services (Norain et. al 2015).According to the Department of Statistics Malaysia (2018), the total number of caterer services registered in 2010 was 12,318 with a contribution of RM3.6 billion to Malaysia's gross domestic product (GDP) during the year. This number continued to increase by 32.7 percent to 16,348 units in 2015 and contributed RM5.8 billion to the country's GDP in 2015 . This significant increase in the number of caterers was stimulated by the high demand for food and beverage preparation services in the country (Norain et al. 2014). Table 1.1 shows the statistics of the total number of food caterers registered with the Companies Commission of Malaysia (SSM) throughout Malaysia from year 2016 to 2018. The number of caterers registered with SSM increased from year 2016 to 2017. However, in 2018 this statistic dropped to 16, 903 units. This decline is due to the unfavourable economic condition in 2018 (Companies Commission of Malaysia, 2019). 
Table 1.1: Number of Catering Businesses registered with the Companies Commission of Malaysia (SSM) 2016 to June 2018

\begin{tabular}{ll}
\hline YEAR & TOTAL \\
\hline 2016 & 15,096 \\
2017 & 25,660 \\
2018 & 16,903
\end{tabular}

Source: Companies Commission of Malaysia (2019)

Next, table 1.2 below shows the statistics of Muslim food caterers registered with SSM for the year 2017 to 2019. From this data it is clear that the highest number of caterers is in the state of Selangor which is 6,667 in 2017. But the statistics decreased to 4,804 in 2018 and further decreased to 3,376 in 2019. Although the statistics of Muslim caterers in the state of Selangor show a decrease but the state still dominates the highest number of Muslim caterers compared to other states in the Peninsula Malaysia. For the states of Sabah and Sarawak, the statistics in table 1.2 only show catering for the company category only because the categories for the type of sole proprietorship and partnership are not managed by SSM but by the local government of the two states.

Table 1.2: Number of Muslim Catering Businesses registered with the Companies Commission of Malaysia (SSM) 2017 to 2019

\begin{tabular}{llll}
\hline STATE & $\mathbf{2 0 1 7}$ & YEAR & \\
& 2728 & $\mathbf{2 0 1 8}$ & $\mathbf{2 0 1 9}$ \\
\hline Johor & 1247 & 2239 & 1328 \\
Kedah & 1011 & 1240 & 817 \\
Kelantan & 626 & 812 & 755 \\
Melaka & 1562 & 784 & 629 \\
N.Sembilan & 790 & 1022 & 1012 \\
P.Pinang & 2094 & 606 & 395 \\
Pahang & 989 & 842 & 773 \\
Perak & 118 & 987 & 701 \\
Perlis & 6667 & 343 & 277 \\
Selangor & 2307 & 4804 & 3376 \\
Terengganu & 1941 & 780 & 571 \\
WP K.Lumpur & 31 & 1295 & 972 \\
WP Labuan & 223 & 31 & 35 \\
WP Putrajaya Sabah Sarawak & 133 & 127 \\
& 1 & 5 & 0 \\
Total & 10 & 10 & 3 \\
\hline
\end{tabular}

Source: Companies Commission of Malaysia (2020)

By comparing the statistical data in Table 1.1 and Table 1.2, it shows that Muslim caterers in Malaysia dominate the food and catering services business. For example, the total number of Muslim caterers in 2017 is 22,264 units compared to the total number of caterers 25,660 in that year. This shows that Muslim caterers in the country accounted for 86.76 percent of the total number of caterers in 2017. While for 2018, although the total number of caterers decreased to 16,903 but the percentage of Muslim caterers in that year was 94.3 percent or represented 15,933 .

In line with the growth of catering services, there is also an increase in complaints received by the Ministry of Domestic Trade and Consumer Affairs (KPDNHEP) related to catering services in the country. From only five complaints in 2014, the number continued to increase to 65 in 2018. Table 1.3 shows the types of complaints related to the catering industry received by the Malaysian Consumer Claims Tribunal (KPDNKHEP, 2019). The increase in the number of complaints to some extent reflects that there are entrepreneurs who do not practice the nature of trust in running a business. 
Table 1.3: Types of Complaints Related to the Catering Industry received by the Malaysian Consumer Claims Tribunal (TTPM) Ministry of Home Affairs and Consumer Affairs (KPDNKHEP)

Types of Complaints
Food prepared is not as ordered
Food served is not enough
Delay in food delivery
The service provided is not as promised
Poor food quality
Customer satisfaction is not emphasized
Insufficient guest server
Less professional service
Failed to provide the service as agreed
Compensation is not paid if the booking cannot be fulfilled as promised

In addition, the printed and electronic media often display issues related to catering services such as wedding catering package fraud (Farizul Hafiz 2018) and issues such as food not enough during events due to the appointed caterers do not fulfil their agreements with customers (Mohamad Azim 2018). This is something that needs to be taken into account by various stakeholders, especially Muslim catering entrepreneurs in this country. If this issue is not addressed and taken lightly it will probably tarnish the overall image of entrepreneurs in this industry.

Meanwhile, according to Ramalingam et al (2012), food safety issues such as viruses in raw materials and illegal processing methods are global issues that are often discussed in the food industry. There are a handful of catering entrepreneurs who do not comply with halal and hygiene and safety standards set by the Department of Islamic Development Malaysia (JAKIM) and Ministry of Health Malaysia (MOH) (Norain Mod Ari et al. 2015; Official Portal of Halal Malaysia, 2018). Apart from that, the statistics for 2020 show that out of 302 restaurant and catering companies that have JAKIM halal certificates in Selangor, there are only 29 catering companies that are registered or have JAKIM halal certification (Official Halal Portal Malaysia, 2020). This to some extent reflects whether these entrepreneurs really practice the nature of trust to customers by taking into consideration or sensitive to halal toyyiban issues.

Furthermore, according to Agung and Husni (2016), in the Islamic perspective, if an individual maintains his trust in Allah by establishing prayers but he does not uphold trust in his interpersonal relationship, then the individual has not been said to practice trust. Soesilowati (2010) also commented that being a Muslim does not guarantee that the individual's behaviour is also in line with Islam. Thus, through the various issues discussed, this study was conducted to explore the extent to which successful entrepreneurs in the food catering services industry in Malaysia practice the nature of trust in their business.

\section{Literature Review}

In Islam, entrepreneurship is a job that is highly regarded by Allah S.W.T. Among the goals of Islamic entrepreneurship according to SarimahHanim and Abdul Rashid Mohd Ali (2010) is to find halal sustenance with hard work for self, family, and ummah development. In fact, all the wealth that God created is enough for everyone in this world. Thus, human beings play a role in carrying the trust by using all the wealth well and honestly, and they will be held accountable for what they have done. Apart from that, entrepreneurship is also considered as an act of worship and jihad fisabilillah wherebyentrepreneurs' aim should not only to seek personal gain, but also fulfill the demand of fardhukifayah that is entrusted to them. In addition, MohdAdib Abd Muin et al. (2014) explained that the concept of Islamic entrepreneurship must also be based on the business practices of the Prophet Muhammad S.A.W as he is the symbol of success and excellence of Muslim entrepreneurs. Rasulullah S.A.W practiced four qualities in his business affairs namely siddiq, amanah, tabligh and fathonah which made him a successful entrepreneur during his time.

Next, in order to maintain relationship with Allah, fellow human beings, and the environment, entrepreneurs need to adhere to aqidah as the main axis in carrying out business activities. Meanwhile, syariah should be used as a guideline so as not to stray from the path of Islam. Morality is an attitude that will reflect the personality of a Muslim (Mohd Aris et al. 2018). Accordingly, in the context of maintaining human relations, Muslim entrepreneurs are required to carry out business activities honestly and with trust (Ramadani et al. 2015: Mohd Zain Mubarak et al.2015; MohdAdibMuin et al. 2014; and PRM Faizal et al. 2013; Shuhairimi Abdullah, 2013; AH Fatimah-Salwa et. Al 2013a, 2013b; Kalsom\&Mohd Ismail, 2010; and Wan Sabri, 2003), keep promises (Pillars and Ahmed 2015; RN Kayed, MK Hassan, 2010; Wan Sabri 2003), avoid betraying any parties (Mohamad et al. 2019), integrity (Mohamad et al. 2019), be fair (Kalsom and Mohd Ismail, 2010; Kalsom and Ahmad Rafiki, 2014) and avoid usury or corruption (Rohana Yusof 2012). By practicing all these morals all the business profit gained will be blessed by Allah (Ramadani et al. 2015). 


\subsection{Trust in Entrepreneurship}

In Islam, entrepreneursareregarded as the caliphs of Allah who are given responsibility of holding the trust to govern this world to the best of their ability (Mohd Aris et al. 2018). Entrepreneurs who have the nature of trust will feel that running a business is a responsibility entrusted by God. Thus, they will always maintain relationship with God, fellow human beings, and with the environment (Abd Muin et al. 2014). Entrepreneurs need to find property, but it needs to be obtained in a good way and trust that is through honest transactions between sellers and buyers, as well as trust in every item sold. However, in doing so, they should not neglect to carry out their trust to Allah by fulfilling the obligation of prayer, zakat and so on. Without the nature of trust, Muslim entrepreneurs will experience difficulties in terms of obtaining maximum profit and blessings (Azman et al. 2015).

Trust is one of the qualities that is often emphasized by the Prophet S.A.W in his life. According to Al Bakri, Zulkifli Mohamad (2013) trust is among the signs of his prophethood that throughout the life of the Prophet SAW for 63 years, he was a trustworthy person, never lied, never betrayed, never spoke bad things, and never even crossed his mind to do evil things. His life was always in the truth until he died.

The demand for human beings to practice the nature of this trust is explained in the Qur'an in surah al-Anfaal (8) verse 27 whose translation is as below. According to Basmeih, Sheikh Abdullah (2010) the meaning of betraying Allah and His Messenger in this verse 27 is by abandoning His commands and violating His prohibitions. Betraying trust is the trust of people whether in the form of property or secrets or whatever.

According to Basmeih (2011) betraying the trust of Allah and His Messenger means neglecting His ordinances and transgressing His prohibitions. To betray people's trust means to betrays trusts either in the form of property, or secret confidence, and such like.

\section{Meaning:}

"O believers! Do not betray (the trust of) Allah and His Messenger, nor (knowingly) betray your trusts."

(al-Anfal 8: 27)

Table 1.4 shows the definition of trust by past researchers. It can be concluded that trust includes several elements such as integrity, responsible and accountable, keeping promises, fair, avoiding usury and corruption, avoiding treachery and always remembering God.

\section{Table 1.4: Definition of trust by past researchers}

\begin{tabular}{lll}
\hline Source & & Definition of Trust \\
\hline Mohd & Adib Abd & Being honest in all things as Allah says in the Qur'an, Surah AnNisa 4:58 and \\
& Muin(2014) & Surah Al Baqarah 2: 188.
\end{tabular}

M. Fahri (2016) Honesty, trust, and peace. Trust is divided into two category, namely the trust from Allah to man and the trust of man to Allah as Allah says in the Qur'an, Surah Al-Ahzab 3:72. Trust also refers to the ability to be fair in religious duties and delegate to others to preserve their rights.

\begin{tabular}{ll}
\hline $\begin{array}{l}\text { MohdHasrulShuhairi } \\
\text { MohdFauziHamat (2015) }\end{array}$ & danPeace of mind. It has to do with the nature of being responsible and accountable. \\
\hline Al Ghazali (m505h) & $\begin{array}{l}\text { The word trust is taken from the word al-amn which refers to a person who feels } \\
\text { secure from the act of infringing on another's rights. It also refers to obedience } \\
\text { and worship as well as associating imperfect faith to someone who does not } \\
\text { uphold trust. }\end{array}$
\end{tabular}

Mohamad et al. (2019) The nature of integrity, responsibility, and honesty in exercising all rights involving rights with God and fellow human beings.

Muhammad Syafii AntonioThe nature of 'trust' means trustworthy. It is the main capital in developing (2013) social trust. Trust covers seven (7) dimensions namely fair, keeping promises, reliable, openness, transparency, mental and physical health, and responsibility and accountability.

Muhammad Syafii Antonio (2013) in the Prophetic Leadership Management Wisdom (PROLM) model in 2005 highlighted trust as a platform for interpersonal capital. According to this PROLM model, Muslim leaders need to practice the four obligatory attributes of the Prophet S.A.W, one of which is trust. This is because among the 
secrets of the success of Rasulullah S.A.W lies in the noble character which is reflected through the four obligatory attributes namely siddiq, amanah, fatanah and tabligh.

\subsection{The Nature of Trust and Entrepreneurial Success (al-falah)}

Successful entrepreneurs are entrepreneurs who conduct business by applying Islamic principles and ethics. They practice the virtues of Rasulullah S.A.W namely siddiq, amanah, tabligh, and fatonah, and adhere to the maqasidsyariah for the benefit of the ummah (Mubarak et al. 2015). Religious moral values practiced are proven to be a major factor in the success of entrepreneurs in the business conducted (Yaakub et al. 2018). In the history of Islam, Rasulullah S.A.W himself was known as a successful entrepreneur. He practiced the principles of Islam and his obligatory attributes namely siddiq, amanah, tabligh, and fatonah in business (Rahman, Afzarur. 1995). It proved to give him double profits without any element of fraud and unethical marketing tactics, which in turn enable him to expand his business to Yemen, Syria, Iraq, Jordan, and other cities in the Arabian Peninsula (Rahman, Z.A., 2014).

In addition, the nature of trust highlighted by entrepreneurs can build confidence and trust of various parties towards their businesses (Mohd Aris et al. 2018), indirectly influence customers' commitment and loyalty (Mohamad et al. 2019), help to viable business, and have efficient and responsible financial management (Mubarak et al. 2015). According to Mohd Zain et al. (2017) trust has a significant relationship with the success of business conducted. According to Tunggak and Ahmed (2015), entrepreneurs are responsible for bearing all the consequences of actions, behaviours, transactions and all matters involved in business, and everything will be questioned in the hereafter. Therefore, entrepreneurs must fulfil all agreements made with stakeholders in order to sustain good reputation of their business. In fact, they must also hold the trust as best as they can and stay away from engaging in usury or corruption that can affect the non-blessing of the sustenance that God has bestowed (SuhailaNadzri and SalmyEdawati Yaacob, 2019).

In Surah al-Mu'minun (23) verses 1 to 11, Allah S.W.T explains about the seven characteristics of a successful believer, one of which is a person who keeps trust and promise. According to Aminuddin et al. (2016) in the 8th verse of surah al-Mu'minun, Allah emphasizes the importance of carrying out responsibilities with trust as one of the characteristics of the believers who will obtain the highest level of Paradise. Apart from that, Basmeih (2011) explained that verse eight (8) highlights one of the signs of successful believers is those who when given the trust, they do not betray, in fact they will take care of and hand it over to their master; and when they promise, they do not break it, in fact they will fulfill it; because the act of treachery and breaking the promise is the nature of hypocrites, as mentioned in the hadiths of the Prophet S.A.W.

\section{Meaning:}

"Successful indeed are the believers, and those who are true their trust and pledges." (al-Mu'minun 23: 1 \& 8)

Therefore, the characteristic of trust is vital to be practiced in order to ensure sustainability and competitiveness of the entrepreneurial business. In addition to gaining success in terms of business profits in the world, entrepreneurs will also get blessings and rewards in the hereafter.

\section{Methodology}

This study uses a qualitative approach to case studies through semi-structured interviews with eight participants (PK) consisting of successful entrepreneurs in the food catering services sector in Selangor. The selection of the state of Selangor is due to the state having the highest number of Muslim food catering entrepreneurs in the country (refer to Table 1.2). The benchmark for PK selection is entrepreneurs who have been in business for more than 10 years, have had an increase in the number of employees and annual income, and have a good reputation among industry competitors. The sampling methods used are purposeful sampling and snowball. The snowball method as suggested by Creswell (2005) is a good strategy to identify the actual study sample starting with one sample then adding until it feels sufficient (saturated). This method facilitates the researcher to obtain a PK that has the same characteristics as the PK that has been interviewed.

Data related to the nature of entrepreneurial trust is obtained through library research such as from journals, conference papers, reference books and official portal sites of relevant government agencies. While the interview protocol was adapted from Norma Yunus (2015); Mohd Zain Mubarak (2015); Fatimah Salwa et al 2013a; 2013b; Sailan, Muhamad Zan (2013); S. Abdul Kadir 2012 and Dede RahmatHidayat (2011). A pilot study was conducted on two PKs in the food service sector in Shah Alam and Putrajaya. The transcribed interview data were analysed using atlas- ti 8 software to extract appropriate themes and categories. The themes obtained have also undergone expert review for the validity of the theme using the calculation of 'cohen kappa'.

\section{Finding and Discussion}


The findings of this study will be discussed as below:

\subsection{Entrepreneur Profile}

Table 1.7 summarizes the profiles of eight catering entrepreneurs interviewed consisting of three women and five men. For the education category, six of the entrepreneurs interviewed received formal education at the university level while two others were educated at the secondary level of SPM (Sijil Pelajaran Malaysia) and STP (Sijil Tinggi Pelajaran).

In terms of experience involved in catering business two PKs have experience involved in catering between 10 to 19 years, five are in the catering industry for 20 to 29 years and another namely PK-H has more than 30 years' experience in the industry. All the PKs interviewed had been involved in the catering world before they registered their business with SSM. In terms of business age, PK-A, PK-D and PK-F have run their catering business between 10 to 15 years and PK-D and PK-E have run their business between 16 to 19 years. While the age of catering business conducted by PK-B and PK-G has already exceeded 20 years. This to some extent shows that the eight PKs are competitive and have managed to stay in the market for a long time even though the industry has fierce competition among Muslim entrepreneurs.

Meanwhile, in terms of business size growth, it was found that all PKs businesses have experienced encouraging growth as shown in the table 1.7. Next in terms of business start-up capital there are seven out of eight PKs which started their business using their own saving, and the business is expanded using existing cash saving without making any loan. Meanwhile, only PK-D started the business using a loan from the Majlis Amanah Rakyat (MARA) agency. In terms of business ownership type, three of the participants interviewed owned a sole proprietorship catering business, one partnership and four others were registered as Syarikat SendiriBerhad.

In terms of gross income, all PKs get an annual return of RM2 million and above. Apart from that, most PKs stated that their annual gross income had increased from year to year except for a slight decrease in 2018 due to the current situation of Malaysia's political economy which was less stable at that time. But they expect an increase in their income when the country's economic situation recovers.

In terms of the number of employees, all PKs stated that their number of permanent employees has increased compared to when they first entered the catering business. PK-A and PK-F have the least number of employees which is between 15 to 20. While PK-E has the most employees which is more than 60. Finally in terms of JAKIM Halal status, only PK-C and PK-E have halal status for their catering business. While the other six do not have JAKIM Halal certificate. However, three of the six PKs who do not have JAKIM halal certificate have applied and some are still in the process of documentation and improvement as directed by JAKIM.

Table 1.7: Theme of Food and Event Catering Entrepreneur Profile

\begin{tabular}{lll}
\hline SUB THEME & CATEGORY & $\begin{array}{l}\text { NUMBER\&PARTICIPA } \\
\text { NTS' CODE(PK) }\end{array}$ \\
\hline Gender & Female & $3(\mathrm{~A}, \mathrm{D}, \mathrm{F})$ \\
& Male & $5(\mathrm{~B}, \mathrm{C}, \mathrm{E}, \mathrm{G}, \mathrm{H})$ \\
\hline Education & Formal - university & $6(\mathrm{~A}, \mathrm{~B}, \mathrm{C}, \mathrm{D}, \mathrm{F}, \mathrm{G})$ \\
& Informal & $2(\mathrm{E}, \mathrm{H})$ \\
\hline Experience in Catering & $10-19$ years & $2(\mathrm{~A}, \mathrm{~F})$ \\
& $20-29$ years & $5(\mathrm{~B}, \mathrm{C}, \mathrm{D}, \mathrm{E}, \mathrm{G})$ \\
& More than 30 years & $1(\mathrm{H}))$ \\
\hline Age of Catering Business & $10-15$ years & $3(\mathrm{~A}, \mathrm{D}, \mathrm{F})$ \\
& $16-19$ years & $2(\mathrm{D}, \mathrm{E})$ \\
& $20-29$ years & $2,(\mathrm{~B}, \mathrm{G})$ \\
& More than 30years & $1(\mathrm{H})$ \\
\hline
\end{tabular}




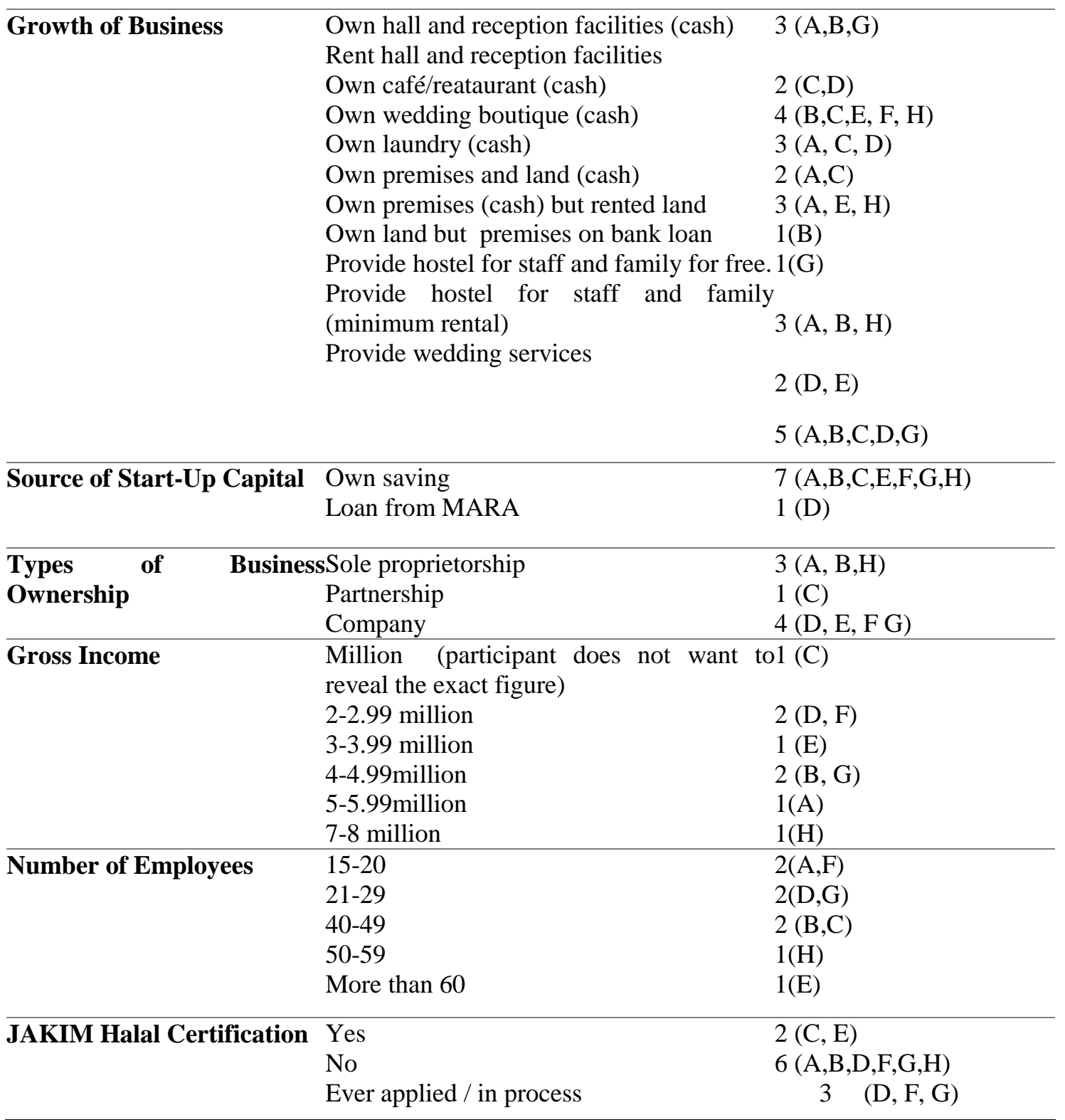

Theme of Trust Practices among Entrepreneurs in Food Catering Business

The findings of the theme of trust practices in business among catering entrepreneurs are summarized as in Table 1.9. PKs' responses show that the theme of this trust practice can be divided into seven subthemes such as responsibility, avoid usury and corruption, keeping promises, high integrity, fairness, avoiding treachery, and finally always remembering Allah as a servant and caliph (protect Allah's rights). Each of these subthemes will be discussed in detail in the next section.

Table 1.9: Sub theme The Nature of Trust among Entrepreneurs

\begin{tabular}{lll}
\hline Theme & ne & ipant's Code (PK) \\
\hline Trust & Responsibility & \\
& Avoid usury and corruption & (A,B,C,D,E,F,G,H) \\
& Keeping promise & (B,D,C, E, F,G, $)$ \\
& High integrity & 7 (A,B,C,D,E,F,G,H) \\
& Fairness & $5(\mathrm{~B}, \mathrm{C}, \mathrm{D}, \mathrm{E}, \mathrm{E}, \mathrm{F}, \mathrm{G}, \mathrm{H})$ \\
& Avoiding treachery & 6 (B, C, D, E,F,G) \\
& Always remember Allah & $4 \quad(\mathrm{C}, \mathrm{D}, \mathrm{F}, \mathrm{G}, \mathrm{H})$ \\
\end{tabular}

\subsubsection{Sub Theme Responsibility}


All PKs have understanding whereby the practice of trust in entrepreneurship refers to the duties or responsibilities of employers to their employees, to customers, and to the communities. While some PKs also mentioned other responsibilities that entrepreneurs have to fulfil.

Regarding responsibility to employees, all PKs highlighted that entrepreneurs have to take care of the needs and welfare of their employees. Some of the PKs mentioned examples such as ensuring that employees' salaries are paid immediately, food and drink are provided for free or partially paid, EPF and SOCSO are paid, and bonuses are given if the business achieves the target (based on employees' performance). There are also PKs who ensure that eid token is given every year to all employees as assistance to purchase necessities for the eid celebration. There are also PKs that provide financial assistance to employees or family members of the employees in order to ease the financial burden of the particular employees. Meanwhile, PK-G provides panel clinic and insurance to facilitate employees to get good health care services.

All PKs strongly emphasized the responsibility to ensure that satisfaction and best service quality are provided to customers. There are various ways to do this such as preparing a feedback form, asking customers to list their dissatisfaction, and discussing with customers. According to PK-A, by doing such approach, he will be able to find out the level of customer's satisfaction and any problem or dissatisfaction will be discussed with the customer to find a solution point.

All PKs interviewed carry out social responsibilities to the community through charity, such as by donating to orphanages and religious school (tahfiz). For example, PK-F's annual routine is to allocate seven to ten percent of his revenue during the month of Ramadan to Yayasan An-Nandhoh in Penang. Meanwhile, PK-H said his father, who is the founder of the company, often donates food or money every Friday to the orphanage and tahfiz in $\mathrm{Sg}$ Tangkas and Bangi, Selangor. Meanwhile, PK-D takes the approach of carrying out social responsibilities by providing employment opportunities to former drug addicts and prisoners.

On the other hand, PK-G is active in an NGO called the Rakan Jihad Bisnes (RJB)by providing opportunities to Malay entrepreneurs who own small size food business, to provide side dishes for certain ceremonies or events performed by his company.

There are also PKs that touched on the aspect of trust in terms of responsibility to parents or families. According to PK-A he takes care of his mother since before he involve in the catering business until now. He is confident that one of the secrets of his business success is because he does not neglect his responsibilities to his mother. The same goes for PK-H who also took care of his late mother and mother-in-law. While PK-D highlighted on the aspect of responsibility to the suppliers by ensuring that the debt is paid immediately without delay.

On the other hand, PK-D, PK-F, PK-G and PK-H explained on the nature of trust in terms of the obligation to obey God's command such as to pay zakat on income and business, to ensure employees perform prayers by encouraging them to perform congregational prayer (entrepreneurs have to lead the prayer), to ensure employees do not commit immorality in the workplace and strengthen their faith by organizing religious talk on weekly basis, and including elements of prayer care in the evaluation of the work performance of their staff. In the initiative to encourage all staff to perform prayer, all PKs provide male and female prayer room (musolla) in the office and close to the kitchen which makes it easier for kitchen workers to perform their prayers.

The findings of this sub-theme on responsibility are in line with Mohd Aris et al. (2018) and Abd Muin et al. (2014) in which entrepreneurs who have the nature of trust will perform the responsibilities entrusted to them by God as best as possible by maintaining relationship with humans and God.

\section{Sub Theme Avoid Usury and Corruption}

For this sub theme, there are three categories identified, namely, PKs do not enter tender to avoid getting involved in corruption and monopoly; PKs do not make bank loans or use credit cards to avoid getting involved with usury; and PKs do not use middlemen (cable) to lobby for tenders.

For example, for the first category there are two PKs, namely PK-D and PK-F who rather use quotation methods to get clients. They do not apply tenders from any government agencies. This is because they have doubt on the existence of incorrect elements in obtaining tenders such as corruption and fraud.

In total, there are six out of the eight PKswho highlighted on the sub-theme of trust in terms of avoiding usury or corruption. The practice of PKs which avoid being involved in usury or corruption is a characteristic of successful entrepreneurs as stated by Mohd Zain Mubarak (2016). This finding is also in line with Rohana Yusof (2012) and SuhailaNadzri and SalmyEdawaty Yaacob (2019) who stated that the practice of usury will deplete property and it must be avoided by entrepreneurs who want to succeed in business.

\section{Sub Theme Keeping Promise}


All PKs emphasize the aspect of keeping promises to customers and all stakeholders, especially in terms of food menus and services provided. In addition, they also fulfill promise in terms of time. The emphasis of all PKs on the sub-theme of keeping promises shows that they practice the morals of successful entrepreneurs. This is because keeping promises is one of the characteristics of successful entrepreneurs (BuerahTunggak and HussinSalamon 2011; Mohd Zain Mubarak 2016; and SuhailaNadzri and SalmyEdawaty 2019).

\section{Sub Theme High Integrity}

There are seven PKs that touched on the aspect of trust in terms of their integrity to customers, lawmakers and God. For instance,PK-G said that he once insisted to prepare food at his own central kitchen rather than preparing at his client's kitchen. He prefered to bear higher cost of transporting food everyday to the client's office for the safety of food provided to customers. He did so because the client's kitchen does not meet the specifications as set by the Ministry of Health Malaysia (MOH).

In addition, there are PKs who strictly avoid paying the middleman to get a tender because they do not want to be involved in corruption. For example, PK-D's assertiveness in this matter shows that he has high integrity in the question of his trust in Allah. He confessed that there are people who approach him and volunteer to be his proxy for certain project or tender. But he just refused their offers because he felt inconvenience and has suspicious dealing with middleman.

These findings are in line with Mohamad et al. (2019) who found that among the definitions of trustworthy people are those with high integrity. Thus, the findings show that seven out of eight PKs practice high integrity in business dealing based on Islamicprinciples.

\section{Sub Theme Fairness}

There are five PKs $(\mathrm{B}, \mathrm{C}, \mathrm{D}, \mathrm{E}, \mathrm{H})$ that relate trust with fair practice in the recruitment process as well as fair treatment to employees (without discrimination).

For example, PK-D explained that he hired employees regardless of their background. His employees consist of diverse background such as former drug addicts and prisoners, people with learning disabilities, and graduates from local and international universities.

In addition, PK-B explained if there are any complaints from customers or problems related to his employees, he will listen to both parties involved, such as customers and employees for the sake of justice to both.

According to Kalsom A. and Mohd Ismail A. (2010) and Kalsom Abdul Wahab and Ahmad Rafiki. (2014), justice is something that is important in business and a person who wants to achieve al falah that is the success of this world and the hereafter needs to practice fairness in all things. In fact, according to M. Fahri (2016) trust relates to the ability of a person to be fair in his duties and protect rights of others. Thus, these findings prove that five of the successful PKs in catering business practice fairness in business dealing as it is an element to the nature of the trust itself.

\section{Sub Theme Avoiding Treachery}

In total there are six PKs (B, C, D, E, F and G) that touch on the treacherous sub-theme. There are four categories under this sub-theme, namely do not take away the rights of customers or hosts by reducing the quantity of food, do not betray business partners and competitors, do not compete in terms of price to bring down competitors but compete for quality, and do not alter competitor's information.

PK-B reprimands to a handful of businessmen who took customers' rights and violated their agreements with customers. According to him, if a customer orders food for 1500 guests, caterer must prepare food for that particular amount. Caterer should not reduce the quantity with perception that since the event is conducted during school holiday, with abundant of wedding invitation, guest will eat less. This practice must be avoided since it is an act of betrayal to customers and of course against Islamic principle and practice.

Al-Bakri, Zulkifli Mohamad (2013) explained that treachery contradicts to the nature of trust which means that a person who practices trust is a person who does not betray others. Thus, this suggests that these six PKs stay away from treachery towards others which is the basis for the practice of trust nature itself.

\section{Sub Theme Always Remember Allah}

Five PKs (C, D, F, G, H) stated that to stay long in business, they need to be trustworthy in terms of always remember Allah and obediently carrying out Allah's commands through prayer, zikir, and zakat. In fact, there are entrepreneurs who said that one of the reasons they are able to stay long in business is because they always maintain good relationship with Allah such as by performing the five daily prayers as well as stay at night to perform additional prayers. For example, PK-D stated that his mother, who is the owner of the catering company, 
often advised him to always take care of his prayers and maintain his relationship with Allah if he wanted to succeed.

As for $\mathrm{PK}-\mathrm{H}$, he said that his father, who is the owner of the catering company, always kept his prayers five times without delay. In fact, according to $\mathrm{PK}-\mathrm{H}$, this factor is one of the secret recipe which enable the company to succeed and sustain for more than thirty years in this industry.

This finding is in line with previous studies which highlighted that the characteristics of successful entrepreneurs are those who do not neglect to remember Allah (Mohd Zain Mubarak 2016; and Fariza Md Sham et al (2017).

\section{Conclusion}

Overall, it was found that all the PKs interviewed practiced the nature of trust in managing their business. This includes seven elements, namely responsibility, keeping promises, high integrity, avoiding usury or corruption, fairness, integrity, avoiding treachery, and always remembering Allah. There are three similarities of the elements of trust obtained in this study and the elements of trust highlighted by Muhammad Syafii Antonio in his Prophectic Leadership Management Wisdom Model (PROLM) (2005) namely responsibility, keeping promises, and fair. This study derives four new elements or sub-themes of trust, namely avoiding usury and corruption, integrity, avoiding treachery, and always remembering Allah.

Meanwhile, four elements of trust in the PROLM Model (2005) are not obtained in this study. There are reliability, transparency, independence, and mental and physical health. This difference may due to the fact that the element of trust highlighted by Muhammad Syafii Antonio, (2005) is more to the element of trust as practiced by Rasulullah S.A.W from the point of view of leadership in organization. In contrast, this study explores the concept of trust from the practical point of view of entrepreneurs in their business transactions. Nonetheless, this study has successfullyanswered the research question whereby the practice of trust is vital that allows entrepreneurs to stay long in the industry.

Finally, the new elements of trust highlighted in this study are expected to be used by other future researchers in studying trust practices among entrepreneurs in various economic sectors.

It is hoped that this finding can be used as a guide for entrepreneurs in catering and food-related industries, as well as in other industries, to always practice the nature of trust so that their entrepreneurial activities will be in line with Islam (BuerahTunggak\&HussinSalamon (2011).

Good qualities (mahmudah) such as trust need to be trained in the soul of individual through continuous riyadah (training) method (istiqamah) which will eventually become a habit (Al-Ghazali 2000). Thus, Muslim entrepreneurs have to make the nature of trust as their habit so that it will enable them to besuccessful in this world and in the hereafter.

\section{Reference}

(30) Juz, Mushaf Malaysia RasmUthmani. Diterbitkan oleh DarulFikirdenganizin dan di bawahkawalanJabatanKemajuan Islam Malaysia (JAKIM)

Abd Muin, M. A., Che Majid, M. F. \& Abdullah, S. (2014). Pengurusankeusahawanansosial Islam: Model usahawanberjayadalamamalannilai-nilaimurni. Prosiding Seminar PenyelidikanKebangsaan.

AfiqMohd Shah. (2018) Pekerja Restaurant Pengotor? Utusan Malaysia. 24 Oktober 2018.

Agung, I. M. \&Husni, D (2016). PengukuranKonsepAmanahdalamPendekatanKualitatif dan Kuantitatif. JurnalPsikologi. Volume 43, No 3, 2016: 194-206 Jabatan Perangkaan Malaysia. (2018) .Banci Ekonomi 2016, StatistikJumlahKatererDiMalaysia (tahunrujukan 2015).

Aminuddin,Z.S.,AhmadBustamam,U.S.,Mahyuddin,M.K.\&Sathiman,S.(2016).Exploring the concept of al-falah (success) in business: An insight from Muslim experts. BEST: International Journal of Management, Information Technology and Engineering.4(8).

Antonio, M.S. (2013). Prophetic Leadership and Management Wisdom (PROLM), Kearifan Profetik Menuju Suksesdengan Seimbang secara Finansial, emosional, Sosial, Fisikal, Intelektual, dan Spiritual melalui Aplikasi Shidiqq, Amanah, Fathanah dan Tabligh. Ensiklopedia, Majelis Ulama Indonesia: Tazkia Publishing.

Azman, A. R., Mohd Dali, N. R. S., S., H., Abdullah, M., Nordin, Siti NurulhudaNooh, M. N., Muhammad, Izlawanie Farah, M. Y. \& Abu Bakar, M. F. (2015) Konsepkeusahawananberteraskanilmunaqli dan aqli. Prosiding International Muamalat and Entrepreneurship Conference.

Basmeih, Sheikh Abdullah (2010). Tafsir PimpinanAr-Rahman kepadaPengertian Al-Qur'an

Creswell, J.W. (2005). Research Design: Qualitative and Quantitative Approaches. London,UK: Sage.

Fahri, M. (2016). Di cari, KepimpinanPerspektif Islam. JurnalBestari. Universitas Muhammadiyah Malang. Ms 153-166. 
Faizal, P.R.M., Ridwan, A.A.M, \&Kalsom, A.W. (2013). The EntrepreneursCharacteristic from Al-Quran and AlHadis. International Journal of Trade, Economics and Finance. Vol. 4. August 2013

Fariza Md Sham, SalasiahHaninHamjah dan Mohd. JurairiSharifudin. (2017). PersonalitidariPerspektif al-Ghazali. Penerbit UKM Press.

Farizul Hafiz Awang. (2018). KeraniRugi RM5000 TawaranPakejPerkhawinan. BeritaHarian 10 Oktober 2018.

Fatimah Salwa A.H, Mohamad-Azahari, A\&Joni-Tamkin,B(2013a).AnEmpiricalEvidence from Malaysia: What Makes the Muslim Entrepreneurs Succeed? International Journal of Economics and Finance. Vol. 5. No. 7;2013, ISSN 1916-971XE-ISSN 1916-9728. Diterbitkan oleh Canadian Center of Science andEducation.

Fatimah Salwa, A.H.,Mohamad-Azhari,A.,Joni-Tamkin,B.(2013b).SuccessfactorsofSuccessful Microcredit Entrepreneurs; Empirical Evidence from Malaysia. International journal of Business and Social science. 4. No 5. mmay2013.

al-Ghazali. (1988). Ihya' Ulum Al-Din. Jil 1-4. Terj. Prof. TK. H. Ismail YaakubMA-Sh.

al-Ghazali. (2000). Ihya' Ulum al-Din. Kaherah: Dar al-Taqwa li al-Turath.

Hidayat, D.R. (2011). PengaruhTretPersonaliti, EtikaKerja dan Sistem Nilai keatasKejayaanPengusaha Kecil Di Tasikmalaya, Jawa Barat, Indonesia. Tesis Ijazah DoktorFalsafah, FakultiSainsSosial dan Kemanusiaan, UKM, Bangi

JabatanPerangkaan Malaysia. (2018). https://www.statistics.gov.my

Kalsom Abdul Wahab dan Ahmad Rafiki. (2014). Measuring Small Firm Entrepreneur's Performance Based on AlFalah. World Applied Sciences Journal. 29 (12): 1532-1539,2014, ISSN 1818-4952, DOI:10.5829/idosi.wasj.2014.29.12.2058

Kalsom, A dan Mohd. Ismail, A. (2010). Compliance to Islamic marketing practices among businesses in Malaysia. Journal of Islamic Marketing. 1:3 (2010) 286-297.

Kayed, R.N, Hassan, M.K. (2010). Islamic Entrepreneur: A case study of Saudi Arabia. Journal of Development entrepreneurship. 15:4 (2010) 379-413

M. Fahri. (2016). Di cari, KepimpinanPerspektif Islam. JurnalBestari. Universitas Muhammadiyah Malang. Ms 153-166.

Merriam, B.S. (2001). Case Study Research in Education: Al Qualitative Approach. California: Josey-BBass Inco.

Mohamad, N., Ishak, M. S. \& Mohd Rashid, S. (2019). Kerelevananpersonalitiusahawan Islam untukmembentukkepercayaandalammengukuhkankomitmen dan kesetiaanpelanggan. Jurnal Islam dan Masyarakat Kontemporari20(1).

MohdAdib Abd Muin, Azizi Abu Bakar \&Shuhairimi Abdullah. (2014). Model Usahawan Berjaya dalamAmalan Nilai-nilaiMurniKeusahawananSosial Islam. Journal of Human Development and Communication. Vol 3 , 2014 (129-141), UNIMAP

Mohd Aris, N., Abas, S. A., Mohd Adnan, S. D., Md Nasir, M. F. \&Jalani, H. (2018). Modul usahawantani Islam. E-Journal of Islamic Thought and Understanding 1(1). doi:10.1017/CBO9781107415324.004

Mohd Zain Mubarak, AsrafHj Ab. Rahman \&Mohd Rafi Yaacob. (2015). ElemenKerohanianDalamKeusahawanan Islam: Kajian terhadapUsahawan Berjaya di Negeri Kelantan. Jounal of Business and Social Development. Volume 3(1) 2015: 43-53. ISSN: 2289-2915. Penerbit UMT

Mohd Zain Mubarak. (2016). Keusahawanan Islam, Rasulullah S.A.W dan SahabatSebagai Ikon Usahawan Berjaya. Penerbit UMK: Universiti Malaysia Kelantan.

Mohd Zain, M., Kasma, M. H., Marwan, I., MohdNazri, M. \& Wan Salihin, W. A. (2017). PengaruhCiriciriKerohanianTerhadapMotivasiUsahawan.JournalofHumanDevelopment and Communication 6: 141 150.

MohdHasrulShuhari\&MohdFauziHamat.(2015).Nilai-nilaiPentingIndividuMuslimMenurut Al-Ghazali. Jurnal Islam dan Masyarakat Kotemporari. Vol 9. Januari 2015: 47-60, ISSN 2289-6325.UNISZA

Muhammad Syafii Antonio. (2013). Prophetic Leadership and Management Wisdom (PROLM), KearifanProfetikMenujuSuksesdenganSeimbangsecaraFinansial, emosional, Sosial, Fisikal, Intelektual, dan Spiritual melaluiAplikasiShidiqq, Amanah, Fathanah dan Tabligh. Ensiklopedia, Majelis Ulama Indonesia: Tazkia Publishing.

Norain Mod Asri, Fariza Ahmad, WookEndut, Norlaila Abu Bakar dan Nurulhuda Md Zahir (2018). PemintaanInstitusiTerhadapPerkhidmatanKatering. JurnalPengguna Malaysia. JPM-Jilid-24-Jun-2015

Norain Mod Asri, WookEndut, SalwahBulis, Atikah Azmi. (2014). ImpakCukai dan CajPerkhidmatanterhadapPermintaanMakanan di Restoran. JurnalEkonomi Malaysia. 48(1) 201499 - 116

Norma Yunus (2015) PersepsiPerniagaTerhadapPengetahuan dan Amalan Etika Perniagaan di Kalangan Pengendali Makanan. TesisSarjana Pendidikan, UKM

Portal Hadis UniversitiTeknologi Mara (UiTM).2020. https://sigir.uitm.edu.my/webhadis.

Portal Rasmi Halal Malaysia. (2020). http://www.halal.gov.my. Senarai Syarikat yang MemilikiSijil Halal.

Portal Rasmi Kementerian PerdaganganDalam Negeri dan Hal EhwalPengguna (KPDNKHEP). (2019). https://www.kpdnhep.gov.my. 
Rahman, Afzarur. (1995). EnsikklopediaSirah, Insan Kamil. Jilid II. Terj. NorhayatiMohd. Noret al. Penerbit Dewan Bahasa dan Pustaka, Kementerian Pendidikan Malaysia, Kuala Lumpur.

Rahman, Z. A. (2014). StrategipemasarancaraRasulullah S.A.W. Selangor: Al-Hidayah House of Publisher SdnBhd

Ramadani,V.,Dana,L.P.,Ratten,V.\&Tahiri,S.(2015).ThecontextofIslamicentrepreneurship and business: Concept, principles and perspectives. International Journal of Business and Globalisation. 15(3): 244261.doi:10.1504/IJBG.2015.071906

Ramalinggam Rajamanickam, Thiyagu Ganesan dan Nitya Ravindran. (2012). Perspektif Global TerhadapPerlindunganPenggunaMelaluiUndang-undangKeselamatanMakanan. Jurnalundang-undang dan masyarakat, penerbit UKM press. 16 JUUM. ms 43-53

Rohana Yusof. (2012). A Model of the Process of Women's Entry into Business Ownership: A Study among Malay Businesswomen in Malaysia. Journal of Governance and Development (JGD). 13 Vol.8, 2012 (13-26)

Sailan,MuhamadZan(2013)PengurusanhotelsecaraIslam:kajianterhadappengurusanmakanan halal di Hotel De Palma Ampang, Selangor. Masters thesis, University ofMalaya.

SarimahHanim Aman Shah dan Abdul Rashid Mohd Ali. (2010). Entrepreneurship. Second Edition, Oxford FajarSdn Bhd.

Shuhairimi Abdullah. (2013). The characteristic of successful Entrepreneurs from Islamic Perspective. Journal of Islamic Human Advanced Research. 3 (6.6.2013). 322-345

Soesilowati, E.S. (2010). Business opportunities for halal products in the global market: Muslim consumer behaviour and halal food consumption. Journal of Indonesian Social Sciences and Humanities, Vol. 3, 151-160.

SuhailaNadzri dan SalmyEdawati Yaacob. (2019). Ciri-CiriAkhlakUsahawan Muslim Berjaya dan Hubungannyadengan Cara PengembanganHartasertaMatlamatHidupMenurutPerspektif Al-Qur'an. Journal of Contemporary Islamic Law, (2019) Vol. 4(1): 8-17e-ISSN: 0127-788X

SuruhanjayaSyarikatMalaysia.(2019).StatistikPendaftaranPerniagaandanSyarikatbagitahun 2016 hingga 2018.

SuruhanjayaSyarikatMalaysia.(2020).StatistikPendaftaranPerniagaandanSyarikatbagitahun 2017 hingga 2019.

Terjemahan Hadis Sunan at-Termizi: Jilid 2: Hadis No 1226.

Tunggak, B. \& Ahmed, Z. (2015). Pengaruhfaktorlatarbelakangterhadaporientasisikap keusahawanandalamkalanganusahawanbeliabumiputeraMuslim.JurnalAkademika85(2): $\quad 29-$ 43.doi:10.17576/akad-2015-8502-03

Tunggak, B. \&Salamon,H. (2011) Mengembalikan Kegemilangan Tamadun Melayu- Islam Menerusi Pemupukan Budaya Niaga Berteraskan Akhlak .Sari-International Journal of the Malay World and Civilisation.29(2)(2011):123-147

Wan Sabri Wan Hussin. (2003). Ciri-ciriUsahawan Berjaya Dari Persepktif Al-Quran. JurnalUsuludin. Bil 18 (2003) $81-110$

Yaakub, Z., Ilyana, N. \& Adnan, M. (2018). Faktor-FaktorKejayaanUsahawan Ikon Majlis Agama Islam Melaka (MAIM). Journal of Advanced Research in Social and Behavioural Sciences 11, Issue 1 (2018) 82-93. PenerbitAkademiaBaru

Yahaya Ibrahim. (2014). Keusahawanan dan DayaSaingDalamSektorPelanconganPulau.PenerbitUniversiti Sultan Zainal Abidin (UniSZA). 